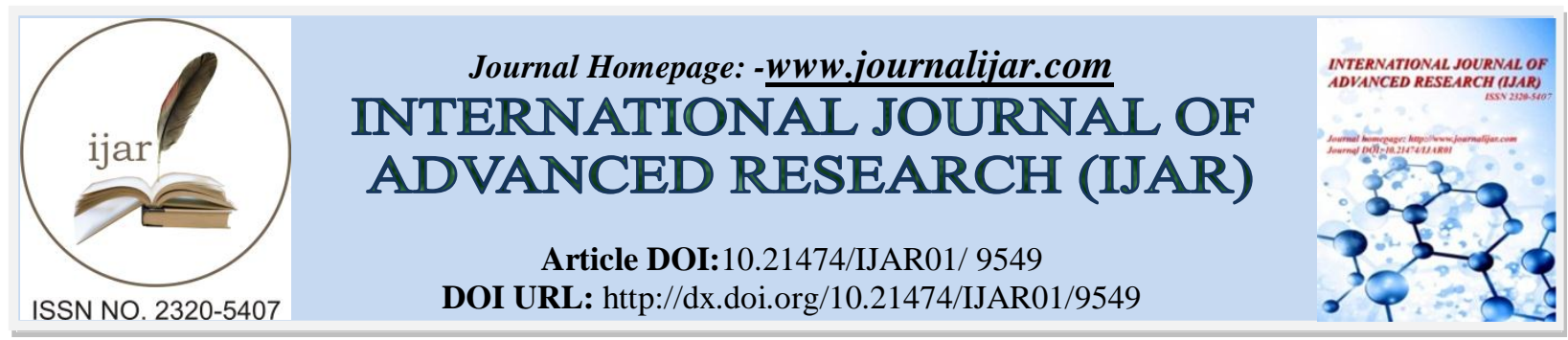

RESEARCH ARTICLE

\title{
THE EFFECT OF ORGANIZATIONAL LEARNING AND WORK ENGAGEMENT ON EDUCATORS INNOVATIVE BEHAVIOR IN SEBASA POLRI.
}

\author{
Gagan Setia Margana ${ }^{1}$, Suparno Eko Widodo ${ }^{2}$, Mukhneri Mukhtar ${ }^{2}$ \\ 1. Student of Educational Managment, State of Jakarta University, Indonesia. \\ 2. Lecture of Educational Managment, State of Jakarta University, Indonesia.
}

\section{Manuscript Info}

Manuscript History

Received: 08 June 2019

Final Accepted: 10 July 2019

Published: August 2019

Key words:-

Organizational Learning, Work

Engagement, Innovative Behavior.

\section{Abstract}

This study aims to determine the effect of organizational learning and work engagement on educators innovative behavior in Sebasa Polri. The research used a quantitative approach with survey methods. This research began from the preparation of proposals to field research, namely from February 2018 to April 2019. The population in this study were 86 educators at the Polri Language School and the research sample when referring to the Slovin formula, obtained 71 educators. The results of this study indicate: organizational learning has a positive direct effect on innovative behavior, work engagement has a positive direct effect on innovative behavior, and organizational learning has a direct positive effect on work engagement. As for the recommendations need to formulate strategies to build a culture of organizational learning as National Police Officers and the educator at Sebasa Polri need to continue to improve their work engagement.

Copy Right, IJAR, 2019,. All rights reserved.

\section{Introduction:-}

Indonesian National Police (Polri) Based on Law No. 2 of 2002 concerning the protection of security and public order, upholding the law, providing protection, protection, and services to the public. Along with the increasing development and change in various fields of life in the community, providing increasingly difficult challenges for the Police in carrying out their duties. It requires the quality of human resources.

Polri in the case and resolve cases involving many countries such as human trafficking, drugs, and cybercrime, must be able to control and communicate with various languages properly and correctly. To improve the ability of Polri personnel to master foreign languages in their institutions, Polri has a Language School (Sebasa). Sebasa whose position under the Republic of Indonesia Police Education and Training Institute is expected to produce Polri personnel who are professional and can communicate in international languages in carrying out their duties so that they can become part of the world-class community. In realizing this vision, the National Police Sebasa formulated the mission: (1) educating police personnel to have language competence, (2) creating professional personnel and when performing tasks capable of using their language skills well, (3) improving the language skills of students so fulfilling the certification requirements in language competency so that it becomes part of the world-class community, (4) seeking expansion and equitable opportunities for obtaining quality language education for Polri Civil Servants, (5) support the Indonesian National Police for foreign language needs, (6) making the National Police Education Institute as a center Police language competency test, and (7) increasing the professionalism of the

Corresponding Author:-Gagan Setia Margana.

Address:-Student of Educational Managment, State of Jakarta University, Indonesia. 
National Police Education and Training Center so that it can become a Center of Excellence in the field of language within the National Police.

In realizing the vision and mission and keeping in mind the changing demands of the task, Sebasa Polri need support from innovative human resources in carrying out their duties. As Nagarajan, Patrick, Tracey, and Ron (2005) stated that in this era of rapid change, organizations face greater demand from their environment to engage in innovative behavior to create and provide competitive services, and to lead the change process itself. An organization to be innovative, the organization must be able to utilize the ideas of their employees because employees are people who develop, carry, react, and modify ideas. This is similar to the results of research conducted by Al Ali (2013) on innovative behavior at the United Arab Emirates Police Institute, that aspects of employee openness to experience, extraversion, emotional intelligence, locus of control, and self-efficacy correlate significantly with innovative behavior.

For Sebasa Polri, the innovative behavior of employees, especially teaching staff in carrying out their duties is very important. Based on observations and preliminary studies on the innovative behavior of educators in the Sebasa Polri environment shown in Table 1:

Table 1:- Innovative Behavior of Sebasa Polri Educators

\begin{tabular}{|l|l|l|}
\hline No & Innovative Behavior of Educators & Average \\
\hline 1 & Actively conducting experiments to find new learning models. & 3,1 \\
\hline 2 & Collecting the latest scientific journals to enrich learning material. & 2,6 \\
\hline 3 & Likes to read new books to get inspiration. & 3,5 \\
\hline 4 & Publish ideas in scientific journals. & 1,6 \\
\hline 5 & Actively writing down his ideas in a wall magazine. & 1,8 \\
\hline 6 & Also offer a solution when Sebasa Polri has a problem. & 2,9 \\
\hline 7 & Make proposals to various parties to obtain research funding support. & 1,2 \\
\hline 8 & Actively discussing with leaders when having ideas that are worth developing. & 2,9 \\
\hline 9 & Ask for input from colleagues when developing new ideas. & 3,4 \\
\hline 10 & No hesitation in applying the new learning method that I developed myself. & 3,4 \\
\hline 11 & Dare to bear the risk of new ideas that I apply in carrying out teaching duties. & 3,4 \\
\hline 12 & Immediately apply when having creative ideas that are useful in completing work. & 3,3 \\
\hline \multicolumn{2}{|l|}{ Total Average } & $\mathbf{2 , 8}$ \\
\hline
\end{tabular}

Source: Preliminary Research Results on $2018(\mathrm{n}=30)$

Shows that the average score on a scale of $1-5$ innovative behavior of educators is 2.8. This shows that the innovative behavior of the teaching staff at Sebasa Polri is still lacking. Educators have not been seen trying to develop language learning methods to be more easily understood by students.

One important factor needed to encourage the emergence of innovative behavior is organizational learning, this was revealed by Pieterse, Knippenberg, Schippers, and Stam (2010), where innovation behavior can be influenced by various things such as transformational leadership, the ability to learn organization, and knowledge sharing. Yeung, Lai, and Yee (2007) stated that innovation originates from learning activities, therefore learning in the organizational environment must be strengthened. Eldor (2011) also states that the innovative behavior of each member of the organization is a reflection of an organization that carries out learning and encourages organizational competitiveness. Another study conducted by Lin and Lee (2017) proves that organizational learning is a factor that significantly influences innovative behavior.

In addition to organizational learning factors, engagement of members of the organization is also an important driving factor for the growth of innovative behavior. This was stated by Rao and Weintraub (2013) that the innovation process requires full employee involvement to maintain the sustainability and growth of the organization created through the development of creative ideas and their implementation. According to Maden (2015) work engagement can increase the proactive behavior of members of the organization in the workplace both directly and indirectly, and proactive behavior is an important capital for the growth of innovative behavior of organizational members. Previous research by Agarwal (2014), Aryee, Walumbwa, Zhou, \& Hartnell, (2012) also confirms that work engagement has a significant effect on innovative behavior. Individuals who have a 
strong work engagement will show a serious effort in carrying out their duties so that creative efforts will emerge to obtain optimal work results.

In the context of the Sebasa Polri environment, the development of organizational learning is weak, it can be seen that the culture of learning is not yet strong among educators, which causes a weakening enthusiasm to continue to learn and innovate in carrying out their duties. Therefore the existence of organizational learning must be increased in order to create a strong learning culture and encourage innovative behavior. Work engagement in the Sebasa Polri environment is still not ideal, where the enthusiasm and hard work of the teaching staff is lacking, so they lack focus in carrying out and completing their tasks. For this reason, it is necessary to increase strong work engagement to encourage educators to have innovative behavior in carrying out their duties as educators at the Sebasa Polri.

Therefore, in realizing the vision and mission of Sebasa Polri and creating innovative behavior among educators, the influence of organizational learning, and work engagement to innovative behavior must be a concern for Sebasa Polri management. By studying the relationship and influence of existing factors, it is expected to provide an overview and input for the management of Sebasa Polri to improve the quality of educators to behave innovatively.

\section{Theoretical Review \\ Innovative Behavior}

Innovation is a very fundamental factor in achieving the goals of an organization because innovation is an invaluable asset and supports the competitiveness of the organization. As West and Farr cited Kleysen and Street (2001) state that innovative behavior is individual actions directed to produce, introduce or apply new findings that are beneficial at every level of the organization. Tidd, Bessant, and Pavitt (2005) see that innovation is an effort to take advantage of all opportunities available to get benefits, so the ability to see and find opportunities becomes an important factor in innovation. So that the process of innovating, that is finding, choosing, implementing and learning. White \& Bruton (2007) added that innovation requires a combination of creative ideas with resources and experts that enable creative ideas to be translated into something useful..

Scott and Bruce in Neiva, Mendonça, Ferreira, and Francischeto (2017) explain that innovative behavior is the extent to which individuals generate creative ideas, develop plans, promote and practice new ideas. Meanwhile, Bryd and Bryman (2003) said that two dimensions underlie innovative behavior, namely creativity, and risk-taking. Where creativity is the ability to develop new ideas consisting of 3 aspects, namely expertise, the ability to think flexibly and imaginatively, and internal motivation. In line with that, Mokhber, Wan Ismail, Ismail, and Vakilbashi (2015) revealed that innovative behavior means turning creativity into profit, and this is seen when employees use different ways and new ideas in their work.

According to Scott and Burce in Lin and Lee (2017) state that a person's innovative behavior can be divided into three stages, each of which (1) Identifying a problem and creating new ideas or solutions; (2) Seek recognition of innovative ideas and build an alliance with supporters; (3) Building an innovation model so that it is possible to be produced in large numbers and become the preferred way and become innovative ideas Based on the description above, it can be synthesized that innovative behavior is the act of someone in finding creative ideas, promoting ideas, seeking support, and implementing ideas that are directed to increase work effectiveness and make a positive contribution to organizational achievement.

\section{Organizational Learning}

At this time the key to the success of an organization to compete is no longer based on resources but rather the accumulation and utilization of knowledge. Self-learning according to Smaldino, Lowther, Mims, and Russel (2015) is the development of new knowledge, skills, or attitudes when an individual interacts with information and the environment.

Organizational learning according to Vera, Crossan, and Apaydin (2011) is a process of change in the thoughts and actions of individuals that are influenced and embedded in the organization. While organizational learning according to George and Jones (2012) refers more to a process that is used to increase the desires and abilities of organizational members in making a decision that can improve the efficiency and effectiveness of the organization. Furthermore, according to Gill (2000), organizational learning is the result of an ongoing process that includes: (1) assimilating information, (2) translating information into knowledge, (3) applying knowledge to become a real need, (4) receiving feedback for revising the information and reshaping knowledge. Organizational learning is also 
associated with the activity of gathering new knowledge as stated by de Castro, Sáez, López, and Dorado (2007). A similar view is expressed by White and Bruton (2007) which shows that organizational learning is the acquisition of knowledge through the application and mastery of information, devices, and new methods. Škerlavaj and Dimovski (2009) state that organizational learning is a process related to the transformation of information into knowledge and into actions that are then reflected in accompanying behavioral and cognitive changes.

Senge cited by George and Jones (2012) points out five principles in organizational learning. First, personal mastery (personal mastery). Learning that encourages organizations to continuously learn to create members of the organization to become experts in their fields. Second, complex mental models. Learning that puts principles and values together, fosters a spirit of sharing values so that it strengthens the spirit and commitment of organizational togetherness. Third, group learning. Group learning will foster the mutual need for one another and act according to a shared plan. Fourth, building a shared vision. The vision agreed upon by all members of his organization and became an encouragement and commitment to always be together. Fifth, systems thinking, which emphasizes that to create organizational learning, managers must recognize how individual and group levels influence each other.

White and Bruton (2007) describe three factors that determine organizational learning outcomes. First, gathering data and information. The greater the amount and range of data that can be collected, the greater the potential information obtained to help organizations identify critical issues and achieve their goals. Second, sharing information, before the organization acts on the information obtained, then the information that needs to be disseminated and communicated within the organization to be material for learning and become a piece of knowledge. Third, it allows learning within the organization. The organization must have information and communicate it, and do it in a way that allows for learning.

Organizational learning can be measured through four dimensions as described by Jerez-Gómez et al. (2005). First, managerial commitment (managerial commitment); managerial support for a shared vision, mental models, and leadership management. Second, the system perspective (system perspective); includes shared vision, clarity of purpose of vision, and system orientation. Third, openness and experimentation (openness and experimentation); includes openness to new ideas, independence of problem-solving. Fourth, knowledge transfer and integration; include teamwork, team learning, internal knowledge integration, knowledge transfer, group problem solving, and team orientation.

Based on the above study, it can be synthesized that organizational learning is a process that enhances the desires and abilities of members of an organization in processing existing information continuously and to be used as useful knowledge for organizational progress.

\section{Work Engagement}

Work engagement is a concept that illustrates how an employee has enthusiasm, focus, and dedication in his work. Work engagement in this context means there is a strong emotional bond between the employee and his work, so that sincerity arises in working. Byrne (2015) explains that work engagement is a motivational condition, in which a person is psychologically motivated, focused and in tune with work and organizational goals, and flows his emotional cognition to transform work into meaningful and meaningful achievement. Work engagement also refers to psychological involvement and work connection as stated by Dessler (2017) where work engagement is the extent to which organizational employees are psychologically involved, connected, and committed to completing their work. Employees who are bound to experience a high level of connectedness with their work duties, and therefore work hard to achieve goals related to their duties.

As stated by Luthans (2011) work engagement is an emotional form of investment in one's work. Similarly, Park et al., (2013), when there is work involved, a person will feel positive emotions that will encourage more open creativity and thoughts and ideas to implement them. The energy generated by work involvement will encourage companies to innovate so that it will make employees more proactive and responsible. Another view related to work engagement is explained by Mathis, Jackson, and Valentine (2016) where work engagement is the extent to which employees' thoughts and behaviors are focused on organizational success, doing extra effort, being very involved in their work, using business and thought, being active, and fully dedicating in work.

In measuring work engagement, one of the most widely used dimensions is from Schaufeli, Salanova, GonzalezRoma, and Bakker (2002) which consists of three dimensions as follows; (1) work engagement is enthusiasm 
(vigor), which is characterized by a high level of energy and mental endurance at work; (2) dedication, characterized by enthusiasm, inspiration, pride, and challenges; (3) absorption, characterized by the concentration attitude of a person at work.

Employee engagement is also measured in a number of its characteristics, which according to Alfes, Truss, and Gill (2010) these characteristics are bound through three aspects. First, intellectual involvement, which is marked by the desire to get the job done. Second, affective involvement, namely positive feelings about doing a good job. Third, social involvement is shown by actively taking the opportunity to discuss work-related improvements with others at work. To measure work engagement, AON Hewitt (2012) uses simple questions with the Say, Stay, and Strive, models. Where employees are asked to respond about three things: (1) If they say positive things about their organization and act as a supporter, (2) If they intend to remain in their organization for a long time, and (3) If they are motivated to try to give their best efforts to help the organization.

Based on the description above, it can be synthesized that work engagement is a condition of a person's mind, emotions, and behavior that is focused on the success of his work.

\section{Research Methods:-}

This research was conducted at the Polri Language School and is the only Polri Language School in Indonesia. Research time from proposal preparation to field research that is from February 2018 to April 2019. This research is used a quantitative approach with survey methods, which is related to the deductive approach to answer the question of who, what, where, how big, and many other questions to the sample or the entire population to describe attitudes, opinions, behavior, or characteristics of the population. The causal relationships of variables in this study are as follows:

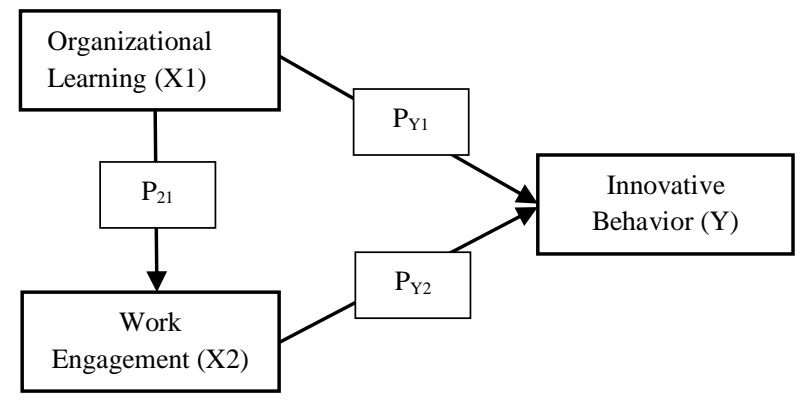

Fig 1:-Research Model

The accesible population in this study is the language educators in the Polri Language School, amounting to 86 educators, and referring to the Slovin formula in determining the number of samples, the number of research samples was 71 Polri Language School educators.

\section{Results and Discussion:-}

The results of descriptive statistical calculations for innovative behavioral variable scores indicate that the ratio of total empirical total score with theoretical total scores is $73.9 \%$, this shows that the innovative behavior of educators is sufficient. The most powerful indicator of innovative behavior is to implement an idea that also confirms that promoting ideas must continue to be encouraged in the Sebasa Polri environment.

Based on the results of the study of organizational learning variables, the ratio of total empirical scores to theoretical total scores is $80.4 \%$, this shows that organizational learning in Sebasa Polri is rated well by educators. And the strongest indicator of organizational learning is spreading information, while the weakest indicator is finding new information. This shows that the activity of finding new information needs to be further strengthened in the Sebasa Polri environment so that organizational learning can run optimally.

The results of the study of work engagement variables, the ratio of total empirical scores to theoretical total scores are $80.5 \%$, so these results illustrate that the work engagement of teachers in Sebasa Polri has been relatively high. 
While the strongest work engagement indicator is the focus on work while the weakest indicator is the commitment to completing the task. These results indicate that there is a need for more maximum efforts to increase commitment to completing tasks for teaching staff in the Sebasa Polri environment.

From the results of simple regression calculations the effect of organizational learning on innovative behavior, the regression equation $\hat{Y}=-3,461+0,949 X_{1}$ was obtained. The summary of the calculation results in the form of ANAVA tables to test the significance and linearity of the regression is shown in Table 2.

Table 2:- ANAVA Table for the Significance and Linearity Regression Test the Effect of Organizational Learning on Innovative Behavior

\begin{tabular}{|l|l|l|l|l|l|l|}
\hline Source of Variance & df & Sum of Squares & Mean Square & F-value & $\begin{array}{l}\text { F-table } \\
(\boldsymbol{\alpha = 0 , 0 5})\end{array}$ & $\begin{array}{l}\text { F-table } \\
(\boldsymbol{\alpha = 0 , 0 1})\end{array}$ \\
\hline Total & 70 & 842340 & & & & \\
Coefficient & 1 & 814806,141 & & & & \\
Regression & 1 & 17007,854 & 17007,854 & $111,490^{* *}$ & 3,980 & 7,017 \\
\hline Residual & 69 & 10526,005 & 152,551 & & & \\
Deviation from Linearity & 40 & 5452,805 & 136,320 & $0,779^{\mathrm{ns}}$ & 1,806 & 2,325 \\
Error & 29 & 5073,2 & 174,938 & & & \\
\hline
\end{tabular}

$* *=$ significant at $\alpha=0,01 ;{ }^{\text {ns }}=$ non significant;

The results of the regression equation the effect of work engagement on innovative behavior, namely $\hat{Y}=-0.588+$ $0.892 \mathrm{X} 2$. A summary of the ANAVA table to test the significance and linearity is shown in Table 3.

Table 3:- ANAVA Table for the Significance and Linearity Regression Test the Effect of Work Engagement on Innovative Behavior

\begin{tabular}{|l|l|l|l|l|l|l|}
\hline Source of Variance & df & Sum of Squares & $\begin{array}{l}\text { Mean } \\
\text { Square }\end{array}$ & F-value & $\begin{array}{l}\text { F-table } \\
(\boldsymbol{\alpha = 0 , 0 5})\end{array}$ & $\begin{array}{l}\text { F-table } \\
(\boldsymbol{\alpha = 0 , 0 1})\end{array}$ \\
\hline Total & 70 & 842340 & & & & \\
Coefficient & 1 & 814806,141 & & & & \\
Regression & 1 & 16074,282 & 16074,282 & $96,786^{* *}$ & 3,980 & 7,017 \\
\hline Residual & 69 & 11459,577 & 166,081 & & & \\
Deviation from Linearity & 44 & 7992,160 & 181,640 & $1,310^{\text {ns }}$ & 1,858 & 2,429 \\
Error & 25 & 3467,416667 & 138,697 & & & \\
\hline
\end{tabular}

$* *=$ significant at $\alpha=0,01 ;{ }^{\text {ns }}=$ non significant;

Test the significance and linearity of the regression effect of work engagement on organizational learning with a regression equation $\hat{X}_{2}=23,590+0.833 \mathrm{X} 1$. The calculation results are presented in table 4 .

Table 4:- ANAVA Table for the Significance and Linearity Regression Test the Effect of Organizational Learning on Work Engagement

\begin{tabular}{|l|l|l|l|l|l|l|}
\hline Source of Variance & df & Sum of Squares & $\begin{array}{l}\text { Mean } \\
\text { Square }\end{array}$ & F-value & $\begin{array}{l}\text { F-table } \\
(\mathbf{\alpha = 0 , 0 5})\end{array}$ & $\begin{array}{l}\text { F-table } \\
(\mathbf{\alpha = 0 , 0 1})\end{array}$ \\
\hline Total & 70 & 1054620 & & & & \\
Coefficient & 1 & 1034435,211 & & & & \\
Regression & 1 & 13115,935 & 13115,935 & $128,026^{* *}$ & 3,980 & 7,017 \\
\hline $\begin{array}{l}\text { Residual } \\
\text { Deviation from Linearity }\end{array}$ & 69 & 7068,853 & 102,447 & & & \\
Error & 40 & 4183,153 & 104,579 & $1,051^{\text {ns }}$ & 1,806 & 2,325 \\
\hline
\end{tabular}

$* *=$ significant at $\alpha=0,01 ;{ }^{\text {ns }}=$ non significant; 
Hypothesis testing results for the influence of organizational learning and work engagement on innovative behavior are presented in table 5.

Table 5:- Recapitulation of Hypothesis Testing Results

\begin{tabular}{|l|l|l|l|l|l|}
\hline No. & $\begin{array}{l}\text { Influence } \\
\text { Variable }\end{array}$ & $\begin{array}{l}\text { Statistical } \\
\text { Hypothesis }\end{array}$ & Path Coefficients & t-value & Result \\
\hline 1. & $\left(\mathrm{X}_{1}\right) \rightarrow(\mathrm{Y})$ & $\begin{array}{l}\mathrm{Ho}: \beta_{\mathrm{Y} 1} \leq 0 \\
\mathrm{H}_{1}: \beta_{\mathrm{Y} 1}>0\end{array}$ & $\mathrm{P}_{\mathrm{Y} 1}=0,486$ & $4,102^{* *}$ & Reject Ho \\
\hline 2. & $\left(\mathrm{X}_{2}\right) \rightarrow(\mathrm{Y})$ & $\begin{array}{l}\mathrm{Ho}: \beta_{\mathrm{Y} 2} \leq 0 \\
\mathrm{H}_{1}: \beta_{\mathrm{Y} 2}>0\end{array}$ & $\mathrm{P}_{\mathrm{Y} 2}=0,373$ & $3,149^{* *}$ & Reject Ho \\
\hline 3. & $\left(\mathrm{X}_{1}\right) \rightarrow\left(\mathrm{X}_{2}\right)$ & $\begin{array}{l}\mathrm{Ho}: \beta_{21} \leq 0 \\
\mathrm{H}_{1}: \beta_{21}>0\end{array}$ & $\mathrm{P}_{21}=0,802$ & $11,315^{* *}$ & Reject Ho \\
\hline
\end{tabular}

** significant at $\alpha=0,01$

The test results show that the hypothesis tested in this study was accepted. This shows that organizational learning and work engagement have a direct positive effect on innovative behavior, and organizational learning has a direct positive effect on work engagement

The results of the calculation of the path coefficient for each variable can then be presented in the following path diagram;

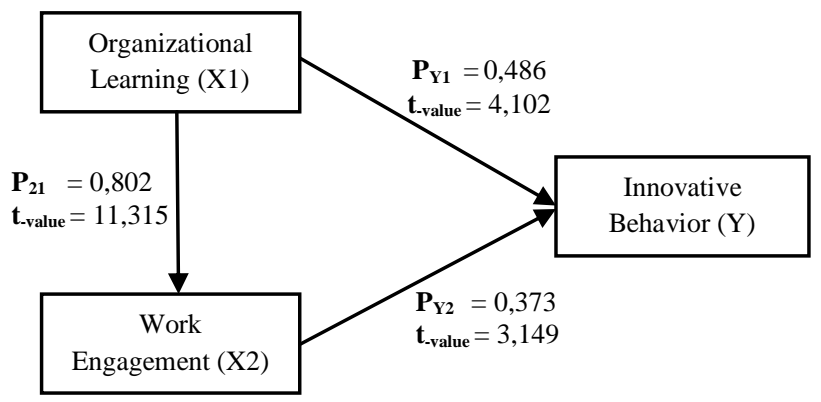

Fig 2:- Path coefficient and T-Value the Effect of Organizational Learning and Work Engagement on Innovative Behavior

Based on the results of the path analysis test, it is known that organizational learning has a positive direct effect on the innovative behavior of educators at Sebasa Polri. Such findings provide an understanding that the practice of organizational learning that goes well, will increase the innovative behavior of educators in the Sebasa Polri. So that organizational learning is a factor that has an important role in determining the level of innovative behavior of educators in the Sebasa Polri environment. Smaldino, Lowther, Mims, and Russel (2015) underline that learning is the development of new knowledge, skills or attitudes. Therefore, learning is the key to innovation.

Based on the results of the analysis of indicator scores, it is known that indicators spreading information have an important role in organizational learning. Hogel et al. cited by Eid and Nuhu (2009) explained that spreading information which is also known as knowledge sharing is a culture of social interaction that involves the exchange of knowledge, skills, and experiences between individuals in the organization. Wang and Noe (2010) argues that sharing knowledge means the provision of task information and knowing how to help others and collaborate with others to solve problems, develop new ideas, or implement policies or procedures.

Previous research also shows that organizational learning as a predictor of innovative behavior, as seen in the research of Lin and Lee (2017) which concluded that organizational learning influences innovative behavior. In another study, it was also found that organizational learning also had a positive effect on innovation (Hui, Radzi, Jenatabadi, Kasim, \& Radu, 2013; Tamayo-Torres, Gutiérrez-Gutiérrez, Llorens-Montes, \& Martínez-López, 2017; Vijande \& Sánchez, 2017). The findings from this previous study provide very clear evidence of the importance of organizational learning in influencing innovative behavior. Therefore, the position of this study is to support the theory and results of previous studies that show the influence of organizational learning on innovative behavior, more specifically in the context of this research, namely the Sebasa Polri. 
Based on the results of statistical calculations about work engagement, it is known that work engagement has a positive direct effect on the innovative behavior of educators in the National Police. These findings reinforce the importance of work engagement factors in the Sebasa Polri environment in enhancing innovative behavior, work engagement regarding the involvement of the individual and the individual's focus on work so that a commitment to get the job done properly appears. Work engagement is also a form of emotional investment in one's work (Luthans, 2011) that conditions can contribute to the emergence of innovation behavior because people who have strong ties to their work will be committed to providing the best so that creative efforts arise in the process completion of work.

Based on the results of the analysis of work engagement indicators it can be seen that the focus on work is very strong, Scott (2011) states that people who focus on their work can ignore various disturbances in the surrounding environment so that at work can think clearly and issue positive ideas that benefit the implementation of its tasks. As stated by Byrne (2015) the focus on work is the main core of work engagement, because those who are bound to work will give more energy and thoughts to work. Therefore, it can be understood why indicators focus on work become dominant in this study so that the impact on innovation behavior will also be big.

Several previous studies also provide strong evidence that work engagement is an important determinant of innovative behavior. This is proven by Agarwal (2014) research by taking employee objects in manufacturing and pharmaceutical companies in Western India and his findings, among others, prove that work engagement has a significant effect on innovative behavior. Likewise, research by Ariyani and Hidayati (2018) and Kim and Park (2017) also found that work engagement was a factor that had a significant effect on innovative behavior. Therefore, this research position means supporting theories and previous studies that show the influence of work engagement to innovative behavior, specifically in this study, which is within the scope of the National Police.

Based on the results of the path analysis states that the positive direct effect of organizational learning on work engagement is accepted. As an implication, the practice of organizational learning that runs well will have an impact on the increased engagement of the work of educators in the National Police. The importance of organizational learning in influencing work engagement has also been proven from the research of Bhaskar and Mishra (2014) which concluded that the two organizational learning factors that most strongly influence work engagement are connecting organizations with the environment and employee empowerment. Other research also found that organizational learning influences work engagement (Eldor, 2011; Lin \& Lee, 2017; Hussein, Abdul Razak, \& Omar, 2017; Malik \& Garg, 2017). By referring to previous theories and research, this study supports previous theories and research on the influence of organizational learning on work engagement.

\section{Conclusions and Recommendation:-}

The conclusions that can be drawn from the results of this study can be explained as follows, first, organizational learning has a positive direct effect on the innovative behavior of educators at the Sebasa Polri. Thus the practice of organizational learning that goes well, will result in increased innovative behavior of educators in the Sebasa Polri. Second, work engagement has a positive direct effect on the innovative behavior of educators in the Sebasa Polri. Thus the higher work engagement will increase the innovative behavior of educators. Third, organizational learning has a direct positive effect on the work engagement of educators in the Sebasa Polri environment. As a result, the practice of organizational learning that runs well will have an impact on increasing the work engagement of educators in the Sebasa Polri. From the conclusions above the novelty of this study is based on the most dominant indicators of each variable, namely: (1) indicators of innovative behavior in implementing ideas, (2) indicators of organizational learning in disseminating information, (3) indicators of work engagement which focuses on work.

Following the conclusions of the research results, then the leader needs to formulate a strategy to build a culture of organizational learning. As a National Police, educators need to be involved in the planning process to determine the programs or activities to be carried out related to organizational learning. Reward systems also need to be implemented to encourage the process of organizational learning, so that every educator is encouraged to find new information that is useful, share and spread information related to organizational learning. Educators in Sebasa Polri also need to continue to increase their work engagement, especially by increasing awareness that work must be done with full dedication and sincerity, building work engagement within each educator, motivational and coaching from the leadership also greatly helps to optimize the work engagement of educators. 


\section{References:-}

1. Agarwal, U. A. (2014). Linking justice, trust and innovative work behaviour to work engagement. Personnel Review, 43(1), 41-73. https://doi.org/10.1108/pr-02-2012-0019

2. Al Ali, O. E. (2013). Exploring the role of individual differences in the prediction of innovative behavior in police organization.

3. Alfes, K., Truss, C., \& Gill, J. (2010). The HR manager as change agent: Evidence from the public sector. Journal of Change Management, 10(1), 109-127. https://doi.org/10.1080/14697010903549465

4. AON Hewitt. (2012). 2012 Trends in global employee Engagement.

5. Aragón-Correa, J. A., García-Morales, V. J., \& Cordón-Pozo, E. (2007). Leadership and organizational learning's role on innovation and performance: Lessons from Spain. Industrial Marketing Management, 36(3), 349-359. https://doi.org/10.1016/j.indmarman.2005.09.006

6. Ariyani, N. and Hidayati, S. (2018). Influence of Transformational Leadership and Work Engagement On Innovative Behavior. Etikonomi, 17(2), 275-284.

7. Aryee, S., Walumbwa, F. O., Zhou, Q., \& Hartnell, C. A. (2012). Transformational leadership, innovative behavior, and task performance: Test of mediation and moderation processes. Human Performance, 25(1), 1-25. https://doi.org/10.1080/08959285.2011.631648

8. Bhaskar, A. U., \& Mishra, B. (2014). Organisational learning \& work engagement: Study of an IT organization. Indian Journal of Industrial Relations, 49(3), 541-550. Retrieved from http://search.ebscohost.com/login.aspx?direct=true\&db=plh\&AN=96441370\&site=eds-live \&scope=site

9. Byrd, J and Brown, P. L. (2003). The Innovation Equation: Building Creativity and Risk Taking in Your Organization. San Fransisco: Jossey-Bass/Pfeiffer.

10. Byrne, Z. S. (2015). Understanding Employee Engagement: Theory, Research, and Practice. London: Routledge.

11. de Castro, G. M., Sáez, P. L., López, J. E. N., \& Dorado, R. G. (2007). Knowledge Creation Processes: Theory and Empirical Evidence from Knowledge-Intensive Firms. New York: Palgrave McMillan.

12. Dessler, G. (2017). Human Resource Management (15th ed.). Essex: Pearson Education, Ltd.

13. Eid, M., \& Nuhu, N. A. (2009). The Impact of Learning Culture and Information Technology Use on Knowledge-Sharing: A Case of KFUPM. In 17th European Conference on Information Systems (pp. 1-13).

14. Eldor, L. (2011). The relationship between perceptions of learning climate and employee innovative behavior and proficiency. Personnel Review, 46(8), 1454-1474. https://doi.org/http://dx.doi.org/10.1108/MRR-09-20150216

15. George, J. M., \& Jones, G. R. (2012). Understanding and Managing Organizational Behavior (6th ed.). New Jersey: Pearson Education, Inc.

16. Gill, S. J. (2000). Organizational Learning. Massachusetts: HRD Press.

17. Hui, H., Radzi, C. W. J. W. M., Jenatabadi, H. S., Kasim, F. A., \& Radu, S. (2013). Influence of organizational learning and innovation on organizational performance in Asian manufacturing food. Asian Journal of Empirical Research, 8(3), 962-971.

18. Hussein, N., Abdul Razak, N. A., \& Omar, M. K. (2017). Learning organization and work wngagement: An empirical evidence of a higher learning institution in Malaysia. Information Management and Business Review, 9(1), 17. https://doi.org/10.22610/imbr.v9i1.1592

19. Jerez-Gómez, P., Céspedes-Lorente, J., \& Valle-Cabrera, R. (2005). Organizational learning capability: A proposal of measurement. Journal of Business Research, 58(6), 715-725. https://doi.org/10.1016/j.jbusres.2003.11.002

20. Kleysen, R. F., \& Street, C. T. (2001). Toward a multi-dimensional measure of individual innovative behavior. Journal of Intellectual Capital, 2(3), 284-296. Retrieved from http://dx.doi.org/10.1108/EUM0000000005660

21. Lin, H. C., \& Lee, Y. D. (2017). A study of the influence of organizational learning on employees' innovative behavior and work engagement by a cross-level examination. Eurasia Journal of Mathematics, Science and Technology Education, 13(7), 3463-3478. https://doi.org/10.12973/eurasia.2017.00738a

22. Luthans, F. (2011). Organizational Behavior: An Evidence-Based Approach (12th ed.). New York: McGrawHill Company, Inc.

23. Maden, C. (2015). Linking high involvement human resource practices to employee proactivity: The role of work engagement and learning goal orientation. Personnel Review, 44(5), 720-738.

24. Malik, P., \& Garg, P. (2017). Learning organization and work engagement: Exploring the nexus in Indian IT sector. Asia-Pacific Journal of Business Administration, 9(3), 166-189. https://doi.org/10.1108/APJBA-032016-0034 
25. Mathis, R. L., Jackson, J. H., \& Valentine, S. R. (2016). Human Resource Management: Esential Perspective (16th ed.). Mason: South-Western Cengage Learning.

26. Mokhber, M., Wan Ismail, W. K., Ismail, S. Z. A., \& Vakilbashi, A. (2015). Leadership and Innovative Behaviors: The Key Drivers for Organizational Innovation. Singapore: Partridge Publishing Singapore.

27. Nagarajan, R., Patrick, C. F., Tracey, S., \& Ron, S. (2005). Determinants of innovative work behaviour: Development and test of an integrated model. Creativity and Innovation Management, 14(2), 142-150. Retrieved

from http://proquest.umi.com/pqdweb?did=878076761\%7B \&\%7DFmt=7\%7B \&\%7DclientId=1917\%7B\&\%7DRQT $=309 \% 7 \mathrm{~B} \& \% 7 \mathrm{DVName}=\mathrm{PQD}$

28. Neiva, E. R., Mendonça, H., Ferreira, M. C., \& Francischeto, L. L. (2017). Innovation in Organizations: Main ResearchResults and Their Practical Implications. In E. R. Neiva, C. V. Torres, \& H. Mendonça (Eds.), Organizational Psychology and Evidence-Based Management. Gewerbestrasse: Springer International Publishing.

29. Park, Y. K., Song, J. H., Yoon, S. W., \& Kim, J. (2013). Learning Organization and Innovative Behavior: Te Mediating Effect of Work Engagement. European Journal of Training and Development. Vol. 38(1/2): 75-94. doi: https://doi.org/10.1108/EJTD- 04-2013-0040

30. Pieterse, A. N., Knippenberg, D. van, Schippers, M., \& Stam, D. (2010). Transformational and transactional leadership and innovative behavior: The moderating role of psychological empowerment. Journal of Organizational Behavior, 31(4), 609-623. https://doi.org/10.1002/job

31. Rao, J., \& Weintraub, J. (2013). How Innovative Is Your Company's Culture?, MIT Sloan Management Review. Vol. 54(3): 29-37.

32. Schaufeli, W. B., Salanova, M., Gonzalez-Roma, V., \& Bakker, A. B. (2002). The measurement of engagement and burnout: A two-sample confirmatory factor analytic approach. Statista, 3(1), 71-92.

33. Scott, J. G. (2011). Attention/Concentration: The Distractible Patient. In M. R. Schoenberg \& J. G. Scott (Eds.), The Little Black Book of Neuropsychology: A Syndrome-Based Approach. New York: Springer.

34. Škerlavaj, M., \& Dimovski, V. (2009). Organizational Learning and Performance in Two National Cultures: A Multi-group Structural Equation Modeling Approach. In W. R. King (Ed.), Knowledge Management and Organizational Learning. New York: Springer Science+Business Media.

35. Smaldino, S. E., Lowther, D. L., Mims, C., \& Russel, J. D. (2015). Instructional Technology and Media for Learning (11th ed.). Boston: Pearson Education, Inc.

36. Tamayo-Torres, I., Gutiérrez-Gutiérrez, L. J., Llorens-Montes, F. J., \& Martínez-López, F. J. (2017). Organizational learning and innovation as sources of strategic fit, 116(8), 1445-1467. https://doi.org/10.1108/IMDS-02-2016-0052

37. Tidd, J., Bessant, J., \& Pavitt, K. (2005). Managing Innovation: Integrating Organizational Change. Chichester: John Wiley \& Sons, Inc.

38. Vera, D., Crossan, M., \& Apaydin, M. (2011). A Framework for Integrating Organizational Learning, Knowledge, Capabilities, and Absorptive Capacity. In M. Easterby-Smith \& M. A. Lyles (Eds.), Handbook of Organizational Learning and Knowledge Management. West Sussex: John Wiley \& Sons, Inc.

39. Vijande, M. L. S., \& Sánchez, J. Á. L. (2017). The effects of organizational learning on innovation and performance in Kibs: An empirical examination. In Developments in Marketing Science: Proceedings of the Academy of Marketing Science (pp. 831-833). https://doi.org/10.1007/978-3-319-50008-9_227

40. Wang, S., \& Noe, R. A. (2010). Knowledge sharing: A review and directions for future research. Human Resource Management Review, 20, 115-151. https://doi.org/10.1016/j.hrmr.2009.10.001

41. White, M. A., \& Bruton, G. D. (2007). The Management of Technology and Innovation: A Strategic Approach. Mason: Thomson Higher Education.

42. Yeung, A. C. L., Lai, K. H., \& Yee, R. W. Y. (2007). Organizational learning, innovativeness, and organizational performance: A qualitative investigation. International Journal of Production Research, 45(11), 2459-2477. https://doi.org/10.1080/00207540601020460. 